\title{
OPEM
}

\section{Antiviral activity of Herba Patrinea (a Chinese medicinal herb) against respiratory syncytial virus in vitro}

\author{
Hongyuan Li*, Shanshan Li, Dianli Liu, Yanmei Dong and Wenjing Tian \\ Department of EpidemiologySchool of Public HealthHarbin Medical University199 Dongdazhi street, Nangang, \\ Harbin, P.R. China
}

\begin{abstract}
SUMMARY
Respiratory syncytial virus (RSV) has long been considered an important cause of severe lower respiratory tract infection in infants and young children throughout the world. Unfortunately, no effective treatment of RSV exists. Therefore, New agents are needed to reduce the impact of RSV. We have studied the anti-viral effect of traditional Chinese midicinal herbs for over ten years and find Herba Patrinea (a Chinese medicinal herb) has the anti-RSV effect in vitro. In this study, the Herba Patrinea was extracted with hot water, condensed and sterilized. The cytotoxicity of the aqueous extract was tested by adding the diluted extract directly to HeLa cells and its effect on anti-RSV was estimated by the CPEI assay. As a result, the median cytotoxic concentration $\left(\mathrm{CC}_{50}\right)$ of Herba Patrinea was $32 \mathrm{mg} / \mathrm{ml}$ by morphological observation, the median effective concentration ( $50 \%$ effective concentration, $\mathrm{EC}_{50}$ ) of the Herba Patrinea against replication of the Long strain of RSV in HeLa cells were $1.25 \mathrm{mg} / \mathrm{ml}$. The selectivity index $\left(\mathrm{SI}=\mathrm{CC}_{50} / \mathrm{EC}_{50}\right)$ is 25.6. Moreover, Herba Patrinea gave a dose-dependent response in inhibiting RSV. In time of addition experiment, Herba Patrinea inhibited replication of RSV in HeLa cells when it was added at $0 \mathrm{~h}, 2 \mathrm{~h}$, and $4 \mathrm{~h}$ after virus infection. In summary, the results of this study suggest Herba Patrinea may be a novel anti-RSV drug and it is worthy of further studying.
\end{abstract}

Key words: Herba Patrinea; Respiratory syncytial virus; Anti-viral effect

\section{INTRODUCTION}

Respiratory syncytial virus (RSV) has long been considered an important cause of severe lower respiratory tract disease in infants and young children throughout the world (Chanock and Finberg, 1957; Gardner, 1973; Glezen and Denny, 1973; Kim and Arroyo, 1973; Martin et al., 1978; Medical research council subcommittee on respiratory syncytial virus vaccines, 1978). Over the last decade, it has also become clear that RSV is also an important pathogen in other age groups including infant and young child, those with compromised cardiac, immune, and respiratory systems of any age, and the elderly (MacDonald et al., 1982; Hall et al., 1986;

*Correspondence: Prof Hongyuan Li, Department of Epidemiology, School of Public HealthHarbin Medical University, 199 Dongdazhi street, Nangang, Harbin, 150001 P. R. China. Tel: 86-451-3620505; Fax: 86-4513648617; E-mail: piaoya@public.hr.hl.cn
Groothuis, 1988; Agius et al., 1990; Flemingand and Cross, 1993; Falsey et al., 1995; Michael et al., 2002). Unfortunately, no effective treatment of RSV exists (Martin et al., 2000). Although Ribavirin is the only drug registered for the treatment of children with RSV-induced bronchiolitis and has been licensed by the Food and Drug Administration, its anti-RSV effect is not determined (Hruska et al., 1982). Additional problems of Ribavirin include high costs of the drug, difficulties with administration and the potential teratogenic and carcinogenic effects (Hebert et al., 1990, Kazufumi et al., 2000). Therefore, new agents are needed to reduce the impact of RSV. We have studied the anti-viral effect of traditional Chinese medicinal herbs for over ten years (Liu Mifeng et al., 2001) and find Herba Patrinea (a Chinese medicinal herb) has the anti-RSV effect in vitro. Now it is reported as followed. 


\section{MATERIALS AND METHODS}

\section{Viruses and cells}

Respiratory syncytial virus (RSV) (long strains) was kindly provided by institution of Chinese preventive sciences. HeLa cells were used as the host for RSV. The cells were grown in the Modified Eagles medium (MEM) with 5\% fetal calf serum (FCS) (Institution of Harbin Veterinary medicine).

\section{Preparation of the Herba Patrinea extract}

Herba Patrine (1000 g) were locally purchased in Harbin and washed five times with tap water and three with distilled water. Then the herbs were soaked with $7000 \mathrm{ml}$ distilled water for 12 hours and extracted at $100^{\circ} \mathrm{C}$ for $90 \mathrm{~min}$. The extract was clarified with cotton cloth and decanted to a clear container. The remainder was extracted one more time. The pooled extract was condensed at $100^{\circ} \mathrm{C}$ to $1.0 \mathrm{~g} / \mathrm{ml}$. The aqueous extract was sterilized at $100^{\circ} \mathrm{C}$ for $30 \mathrm{~min}$.

\section{Cytotoxicity}

The cytotoxic effect of the aqueous extract on HeLa cells was tested. The sterilized aqueous extract was diluted in culture medium (MEM with 2\% (v/v) heat-inactivated calf serum) before added directly to HeLa cells. The culture were incubated at $35^{\circ} \mathrm{C}$ in a $\mathrm{CO}_{2}$ incubator, morphological changes resulting from aqueous extract were observed under an inverted light microscopy. Morphological change scale (MCS) was graded to 0-4 with 4 being defined as complete cytotoxicity. The $50 \%$ cytotoxic concentration $\left(\mathrm{CC}_{50}\right)$ in HeLa cells was calculated using ReedMuench method (Reed, 1938) using the means of the MCS at each concentration of aqueous extract. In this assay the cytotoxic effect of Ribavirin was also observed.

\section{Virus titration in HeLa cells}

Monolayers of HeLa cells grown on 96-well culture plates were infected with various concentrations of respiratory syncytial virus and incubated for 2 hours at $35^{\circ} \mathrm{C}$ in a $\mathrm{CO}_{2}$ incubator. The virus inoculum was removed from the cultures and the culture medium (MEM with 2\%(v/v) heat-inactivated calf serum) was added to the plates. The plates were incubated at $35^{\circ} \mathrm{C}$ in a $\mathrm{CO}_{2}$ incubator for $72 \mathrm{~h}$ and the virus-induced cytopathic (CPE) was observed under an inverted light microscope (CPE score: score $0=0 \%$ CPE, score $1=1 \%-25 \%$ CPE, score $2=25 \%-50 \%$ CPE, score $3=50 \%-75 \%$ CPE, score $4=75 \%-100 \% \mathrm{CPE}$ ). Four wells were set at each concentration and four wells were added with maintenance medium as uninfected, untreated control. The $50 \%$ tissue culture infectious dose $\left(\mathrm{TCID}_{50}\right)$ was calculated by the Reed-Muench method using the means of the $\mathrm{CPE}$ scores at each virus concentration.

\section{CPE inhibition assay}

Monolayers of HeLa cells grown on 96-well culture plates were infected with $50 \mathrm{TCID}_{50}$ RSV. After incubation for $2 \mathrm{~h}$ at $35^{\circ} \mathrm{C}$ in a $\mathrm{CO}_{2}$ incubator, the virus inoculum was removed from the cultures and the extract was diluted in culture medium (MEM with $2 \%(\mathrm{v} / \mathrm{v})$ heat-inactivated calf serum) before added to the plate. The plates were incubated at $35^{\circ} \mathrm{C}$ in a $\mathrm{CO}_{2}$ incubator for $72 \mathrm{~h}$ and the virus-induced cytopathic (CPE) was observed under an inverted light microscope. Ribavirin was used as positive control and the plates overlaid with culture medium without the extract were used as virus control. The median effective concentration ( $50 \%$ effective concentration, $\mathrm{EC}_{50}$ ) of the Herba Patrinea against replication of the Long strain of RSV in HeLa cells was calculated using ReedMuench method. A selectivity index (SI) was also calculated for each compound using the fomula: $\mathrm{SI}=\mathrm{CC}_{50} / \mathrm{EC}_{50}$.

\section{Time of addition experiment}

HeLa cells were infected with virus and incubated $4^{\circ} \mathrm{C}$ for $1 \mathrm{~h}$ to allow viral absorption. Virus inoculum was then removed and cultures were washed three times with pre-chilled medium prior to incubation with culture medium at $35^{\circ} \mathrm{C}$ in a $\mathrm{CO}_{2}$ incubator. At $0,2,4,6$ and $8 \mathrm{~h}$ post-virus infection, the extract and Ribavirin were added to duplicate cultures. The plates were incubated at $35^{\circ} \mathrm{C}$ in a $\mathrm{CO}_{2}$ incubator for $72 \mathrm{~h}$ and the CPE was observed.

\section{RESULTS}

\section{Cytotoxicity}

The cytotoxicity of the extract was tested in HeLa cells. The median cytotoxic concentration $\left(\mathrm{CC}_{50}\right)$ of 
Table 1. The inhibitory effects of Herba Patrinea and Ribavirin on RSV replication

\begin{tabular}{|c|c|c|c|c|c|c|c|}
\hline \multirow{2}{*}{ Drugs } & \multirow{2}{*}{ Dose } & \multirow{2}{*}{$\begin{array}{l}\text { CPE } \\
\text { score }\end{array}$} & \multirow{2}{*}{$\begin{array}{l}\text { Average } \\
\text { CPE score }\end{array}$} & \multirow{2}{*}{$\begin{array}{c}\text { CPE } \\
\text { inhibition }\end{array}$} & \multicolumn{2}{|r|}{ Total } & \multirow{2}{*}{$\begin{array}{c}\mathrm{CPE} \text { inhibitory } \\
\text { rate }(\%)\end{array}$} \\
\hline & & & & & CPE & CPE inhibition & \\
\hline \multirow{7}{*}{$\begin{array}{c}\text { Herba } \\
\text { Patrinea } \\
(\mathrm{mg} / \mathrm{ml})\end{array}$} & 5 & 1011 & 0.75 & 3.25 & 14.50 & 3.25 & 81.69 \\
\hline & 2.5 & 1121 & 1.25 & 2.75 & 11.25 & 6.00 & 65.22 \\
\hline & 1.25 & 1212 & 1.50 & 2.50 & 8.50 & 8.50 & 50.00 \\
\hline & 0.625 & 2112 & 1.50 & 2.50 & 6.00 & 14.50 & 29.27 \\
\hline & 0.3125 & 3223 & 2.50 & 1.50 & 3.50 & 18.00 & 16.28 \\
\hline & 0.156 & 2332 & 2.50 & 1.50 & 2.00 & 20.00 & 9.09 \\
\hline & 0.078 & 3434 & 3.50 & 0.50 & 0.50 & 20.50 & 2.38 \\
\hline \multirow{6}{*}{$\begin{array}{l}\text { Ribarivin } \\
(\mu \mathrm{g} / \mathrm{ml})\end{array}$} & 10 & 0000 & 0.00 & 4.00 & 13.50 & 0.00 & 100.00 \\
\hline & 5 & 1010 & 0.50 & 3.50 & 9.50 & 0.50 & 95.00 \\
\hline & 2.5 & 1221 & 1.50 & 2.50 & 6.00 & 2.00 & 75.00 \\
\hline & 1.25 & 1323 & 2.25 & 1.75 & 3.50 & 4.25 & 45.16 \\
\hline & 0.625 & 3233 & 2.75 & 1.25 & 1.75 & 7.00 & 20.00 \\
\hline & 0.3125 & 4433 & 3.50 & 0.50 & 0.50 & 10.50 & 4.54 \\
\hline \multirow{2}{*}{\multicolumn{2}{|c|}{$\begin{array}{l}\text { Cell control } \\
\text { Viral control }\end{array}$}} & 0000 & 0 & 4.00 & & & \\
\hline & & 4434 & 3.75 & 0.25 & & & \\
\hline
\end{tabular}

Herba patrinea was $32 \mathrm{mg} / \mathrm{ml}$ by morphological observation. $\mathrm{TC}_{0}$ of the extract is $20 \mathrm{mg} / \mathrm{ml}$. No significant cytotoxicity of Ribavirin was observed against HeLa cells by Morphological observation, even at the highest concentration of the Ribavirin examined $(500 \mu \mathrm{g} / \mathrm{ml})$.

\section{Virus titration in HeLa cells}

The $\mathrm{TCID}_{50}$ of respiratory syncytial virus in HeLa cells was $10^{-7.7}$.

\section{CPE inhibition assay}

As it shows in Table 1, the inhibitory effect of Herba Patrinea and Ribavirin on RSV replication was analyzed using KruskalWallis method. As a result, the distribution of CPE scores in those concentrations ranging from 5 to $0.625 \mathrm{mg} / \mathrm{ml}$ of Herba Patrinea were significant different with respect to that of the virus control by KruskalWallis test $(P<0.01)$; the distribution of CPE scores in those concentrations ranging from 10 to $2.5 \mu \mathrm{g} / \mathrm{ml}$ of Ribavirin were significant different with respect to that of the virus control by Kruskal-Wallis test $(P<0.01)$.

The median effective concentration (50\% effective concentration, $\mathrm{EC}_{50}$ ) of the Herba Patrinea against replication of the Long strain of RSV in HeLa cells was estimated as $1.25 \mathrm{mg} / \mathrm{ml}$, and selectivity index (SI) was 25.6. The $\mathrm{EC}_{50}$ and SI of the Ribavirin were estimated as $1.43 \mu \mathrm{g} / \mathrm{ml}$ and more than 349 , respectively.

\section{Dose-depended Inhibition on RSV by Herba Patrinea and Ribavirin}

In order to observe the dose-effect relation, the correlation analysis was done between the logarithmic concentrations and CPE inhibitory ratios for RSV. As it is showed in Fig. 1 and Fig. 2, the correlation coefficient (r) for Herba Patrinea is $0.9849(P=0.0001)$, while $\mathrm{r}$ is for Ribavirin is $0.9859(P=0.0003)$. There existed significant correlations between the logarithmic concentrations and CPE inhibitory ratios for Herba Patrinea and Ribavirin.

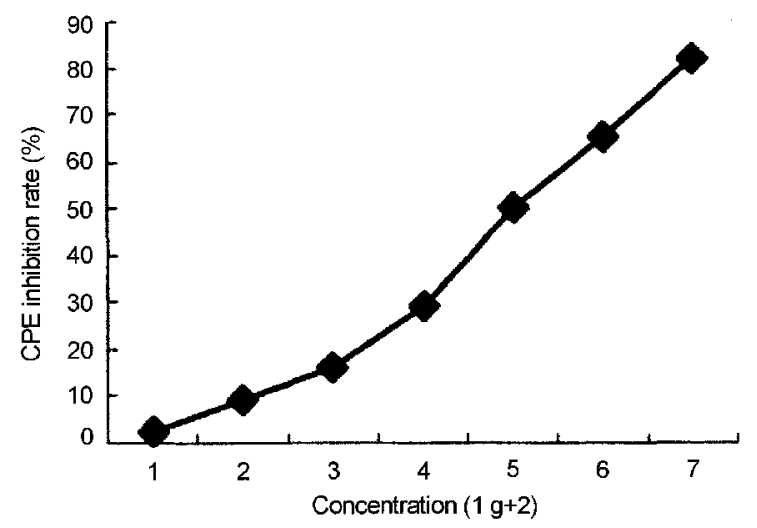

Fig. 1. Dose-depended inhibition on RSV by Herba Patrinea. 


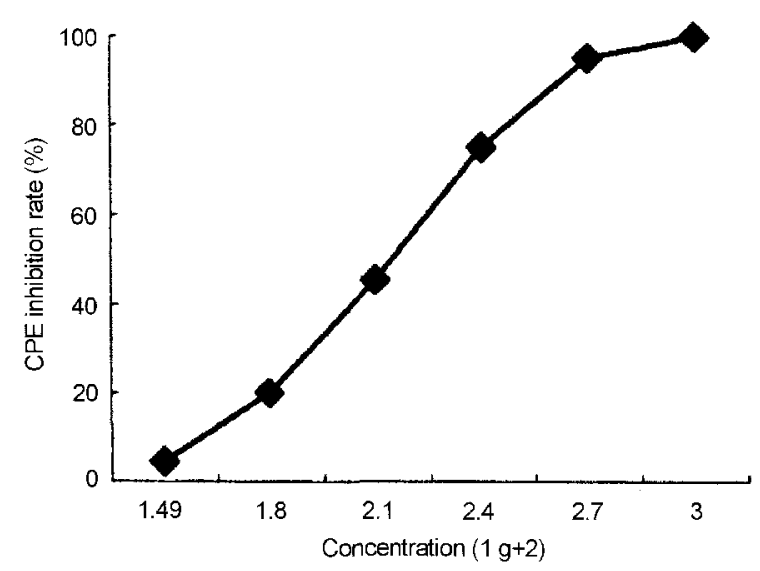

Fig. 2. Dose-depended inhibition on RSV by Ribavirin.

\section{Time of addition experiment}

The inhibitory effect of the Herba Patrinea on RSV replication in HeLa cells was further investigated in a one-step growth study, in which the extract and Ribavirin were added at $0,2,4,6$ and $8 \mathrm{~h}$ postvirus infection. The effect was analyzed by KruskalWallis method. As a result, Herba Patrinea and Ribavirin showed active effect against RSV replication when they were added at $0,2,4 \mathrm{~h}$ after virus infection $(P<0.01)$ (Table 2$)$.

\section{DISCUSSION}

Acute respiratory infectious caused by RSV are known to be most prevalent in infants and children. The mortality of RSV infection is usually low, whereas it increases to $37 \%-73 \%$ in infants with heart or pulmonary failure, and to $36 \%-45 \%$ in recipients of bone marrow transplant (MacDonald et al., 1982; Englund et al., 1988; Harrington et al., 1992). A novel anti-RSV agent with better therapeutic efficacy and safety than Ribavirin is needed. We have studied anti-RSV drugs for over ten years. After screening many Chinese medicinal herbs using cells culture methods, we found that Herba Patrinea had the ability to inhibit the replication of respiratory syncytial virus effectively in HeLa cells. In this study, Herba Patrinea was extracted with hot water at $100^{\circ} \mathrm{C}$ for 90 minutes twice times and condensed at $100^{\circ} \mathrm{C}$ to $1.0 \mathrm{~g} / \mathrm{ml}$. The process is much like the Chinese traditional method of herb extracting and easy to operate. As a result we got $1000 \mathrm{ml}$ brown aqueous extract.

In the assay of cytotoxicity, the aqueous extract was diluted in culture medium (MEM with $2 \%(\mathrm{v} /$ v) heat-inactivated calf serum) and added to HeLa cells. $\mathrm{TC}_{50}$ of the extract is $32 \mathrm{mg} / \mathrm{ml}$.

The inhibitory effect of Herba Patrinea on RSV replication was tested in HeLa cell using several assays. As the results of CPE inhibition assay, the $\mathrm{EC}_{50}$ and SI of Herba Patrinea are $1.25 \mathrm{mg} / \mathrm{ml}, 25.6$, respectively, Furthermore, Herba Patrinea shows a dose-depended effect against RSV.

At $4^{\circ} \mathrm{C}$ RSV binds to cells but not penetrate through the cell membrane. When virus bound cells are exposed to a $35^{\circ} \mathrm{C}$ condition, the virus starts to penetrate the cell membrane (Hosoya et al., 1991). The results of the effect of Herba Patrinea on RSV growth show that Herba Patrinea is a good inhibitor of virus penetration as well as virus replication. The cells were put at $4^{\circ} \mathrm{C}$ after infection with RSV for 60 minutes to allow the virus adsorption and then washed three times. The Herba Patrinea was added before the cells incubated at $35^{\circ} \mathrm{C}$. We found that the virus was totally inhibited by the extract after three days of observation, which suggests that the extract of Herba Patrinea could inhibit virus penetration. In additional, when the extract was added at $2 \mathrm{~h}, 4 \mathrm{~h}, 6 \mathrm{~h}$ post-viral infection, it also

Table 2. Time of addition of Herba Patrinea and Ribavirin to infected cells and inhibitory effects of Herba Patrinea and Ribavirin on RSV replication

\begin{tabular}{cccccc}
\hline Drug & Time of addition & CPE score & Drug & Time of addition & CPE score \\
\hline & $0 \mathrm{~h}$ & 0000 & & $0 \mathrm{~h}$ & 0000 \\
Herba Patrinea & $2 \mathrm{~h}$ & 1102 & Ribavirin & $2 \mathrm{~h}$ & 1101 \\
$(2 \mathrm{mg} / \mathrm{ml})$ & $4 \mathrm{~h}$ & 1122 & $(10 \mu \mathrm{g} / \mathrm{ml})$ & $6 \mathrm{~h}$ & 1321 \\
& $6 \mathrm{~h}$ & 2243 & & $8 \mathrm{~h}$ & 2334 \\
& $8 \mathrm{~h}$ & 4434 & & $8 \mathrm{~h}$ & 4443 \\
\hline Viral control & & 4444 & Virus control & & 4444 \\
Cell control & 0000 & Cell control & & 0000 \\
\hline
\end{tabular}


showed inhibitory effect on RSV replication. Since virus began replicating when incubated at $35^{\circ} \mathrm{C}$, we can conclude that the extract can inhibit virus replication as well. But the mechanism is not clear yet and need further studying.

In summary, Herba Patrinea proved to be potent anti-RSV agent and it is low toxic. As a potential anti-RSV agent, it is worth further investigating.

\section{REFERENCES}

Agius G, Dindinaud G, Biggar RJ, Peyre R, Vaillant V, Ranger S, Poupet JY, Cisse MF, Castets M. (1990) An epidemic of respiratory syncytial virus in elderly people: clinical and serological findings. J. Med. Virol. 30, 117-127.

Chanock RM, Finberg L. (1957) Recovery from infants with respiratory illness of a virus related to chimpanzee coryza agent (CCA). II. Epidemiological aspects of infection in infants and young children. Am. J. Hyg. 66, 291-300.

Englund JA, Sullivian CJ, Jordan MC et al. (1988) Respiratory syncytial virus infection in immunocompromised adults. Ann. Int. Med. 109, 203-208.

Falsey AR, Cunningham CK, Barker WH, Kouides RW, Yuen JB, Menegus M, Weiner LB, Bonville CA, Betts RF. (1995) Respiratory syncytial virus and influenza A infections in the hospitalized elderly. J. Infect. Dis. 172, 389-394.

Fleming DM, Cross KW. (1993) Respiratory syncytial virus or influenza. Lancet 342, 1507-1510.

Gardner PS. (1973) Respiratory syncytial virus infections. Postgrad. Med. J. 49, 788-791.

Glezen WP, Denny FW. (1973) Epidemiology of acute lower respiratory disease in children. New Engl. J. Med. 11, 239-243.

Groothuis JR, Gutierrez KM, Lauer BA (1988) Respiratory syncytial virus infection in children with bronchopulmonary dysplasia. Pediatrics 82, 199-203.

Hall CB, Powell KR, MacDonald NE, Gala CL, Menegus Sun SC et al. (1986) Respiratory syncytial virus infection in children with compromised immune function. N. Engl. J. Med. 315, 77-81.

Harrington RD, Hooton TM, Hackman RC et al. (1992) An outbreak of respiratory syncytial virus in bone transplant center. J. Infect. Dis. 165, 987-993.

Hebert MF, Guglielmo BJ. (1990) What is the clinical role of aerosolized Ribavirin. DICP 24, 735-738.

Hruska JF, Morrow PE, Suffin SC, Douglas RG. (1982) In vivo inhibition of respiratory syncytial virus by Ribavirin. Antimicrob. Agents Chemother. 21, 125-130.

Kazufuumi Kimura, Shuichi Mori, Kiyoko Tomita et al. (2000) Antiviral activity of NMSO3 against respiratory syncytial virus infection in vitro and in vivo. Antiviral research $47,41-51$.

Kim HW, Arroyo JO. (1973) Epidemiology of respiratory syncytial virus in Washington, DC. I. Importance of the virus in different respiratory tract disease syndromes and temporal distribution of infection. Am. J. Epidemiol. 98, 216-225.

Liu Mifeng et al. (2001) The anti-respiratory syncytial virus effect of a Chinese medical herb-No.1 in HeLa culture. Heilongjiang med. J. 14, 266-268.

MacDonald NE, Hall CB, Sun SC, Alexson C, Harris PJ, Manning JA. (1982) Respiratory syncytial virus infection in infants with congenital heart disease. $N$. Engl. J. Med. 307, 397-400.

Martin AJ, Gardner PS, McQuillin J. (1978) Epidemiology of respiratory viral infection among pediatric inpatients over a six year period in northeast England. Lancet 2, 1035-1038.

Martin CJ, Kneyber - Henriette A. Moll - Ronald de Groot. (2000) Treatment and prevention of respiratory syncytial virus infection. Eur. J. Pediatr. 159, 399-411.

Medical Research Council Subcommittee on Respiratory Syncytial Virus Vaccines. (1978) Respiratory syncytial virus infection: admissions to hospital in industrial, urban, and rural areas. Br. Med. J. 2, 796-798.

Michael G, Ison a, John Mills b, Peter Openshaw. (2002) Current research on respiratory viral infections: Fourth International Symposium. Antiviral Research 55, 227-278.

Reed LJ, Muench H. (1938) AA simple method of estimating fifty percent endpoints. Am. J. Hyg. 27, 495-497. 